\title{
Students' Involvement in Decision Making and Their Academic Performance in Embu West Sub-County of Kenya
}

\author{
Alexander Mati, Jane Ciumwari Gatumu*, John Rugendo Chandi \\ Department of Educational Communication and Technology, College of Education and External Studies, University of Nairobi, Kenya
}

Copyright $\odot 2016$ by authors, all rights reserved. Authors agree that this article remains permanently open access under the terms of the Creative Commons Attribution License 4.0 International License.

\begin{abstract}
Although studies have shown that involving students in decisions that impact their educational outcomes may improve their academic performance, little effort has been put in collating students' views on the appropriate extent of such involvement. Students are key stakeholders and beneficiaries of educational outcomes, as well as determinants of examination results. It is therefore important to study the impact of their inclusion into the school key decision systems. Using data from twelve public day secondary schools in Embu West Sub-County of Kenya, this study attempted to seek the views of students on the effect of their involvement in decision- making on two different fronts: choice of schools in which to enroll and formulation of school rules and disciplinary measures for school rule-violators. It was found that students' involvement in the key decisions of their educational process produces motivation, a sense of ownership and therefore a higher inclination to abide by the set rules, personal drive to meet the individual and collective goals, and an overall higher academic performance. It was recommended that students should be involved at all decision-making levels to the extent that is possible and plausible.
\end{abstract}

Keywords Academic Performance, Student Involvement, Student Participation, Decision-making

\section{Nature of the problem}

The Kenyan government has invested significantly on education. This is evidenced by the setting up of various educational commissions, committees, and task forces. One of the earliest such endeavors was the Ominde report of 1964, which sought to reform the education system inherited from the colonial government, so as to make it more relevant to the Kenyan people [1]. This was followed by the National
Committee report on the Education Objectives and Policies, which focused on national unity, socio-economic and cultural aspirations of Kenyans. One significant outcome of this committee was the launch of community-sponsored day secondary schools, commonly referred to as Harambee schools, a term that denotes the communal effort in building of schools. A day school is a collaborative venture between the community and the government, whereby, the community meets the school construction costs, while the government recruits and maintains teachers [1]. Other government initiatives were the Mackay Report of 1981, which led to the establishment of the 8-4-4 system of education; the Kamunge Report of 1988 and the Commission of Inquiry into Education System in Kenya, whose objective was to align the system to the changing circumstances, so that there could be national unity and mutual social responsibility. Although students are key stakeholders and beneficiaries of education results, the government's effort to improve education as seen in the establishment of different task forces, was not directed towards involving them in key decision making systems.

Out of these commissions, committees and task forces has emerged establishment of free and compulsory primary education from the year 2003 [1] to the present day. One of the latent effects of this compulsory primary education is over-enrolment in day secondary schools [2]. This has created a strain on the available resources, a factor that inversely impacts performance in the final national examinations, as is the case of Embu West Sub-County of Kenya [3]. The implication here is that something must be done to influence a better academic performance by the students. Of course, there are various determinants of students' performance [4]. One way may be the need to involve students in making decisions about their school life. This is in connection with what Uhumuavbi [5] alluded to, when he asserted that students' involvement in the choice of the school influences how they perform academically. The focus here is that students who know how to meet their needs 
through responsible decisions are less likely to behave in ways which interfere with their learning [6]. It becomes imperative to investigate students' involvement in choosing their school and rules as a possible contributing factor to their academic performance in Embu West Sub-County of Kenya. The twelve day secondary schools in this sub-county were known not to be performing well at the Kenya National Examinations [7].

According to the Convention on the Rights of the Child, students have a basic right to participate in deciding on issues that affect them [8]. Reviewed literature indicates possible areas of students' participation as choosing their schools and designing their rules [9, 10]. These areas of involvement include parents, teachers and school administrators [2]. As financiers of their children's education, parents feel an entitlement to choose the schools to which they send their children. Often, they are unwilling to involve their children in making those choices, as alluded to by Abagi [11]. From their early age state, students are therefore denied the opportunity to participate actively in making decisions [12]. Thus, students get into their parents-chosen schools and may begin academic activities in low morale, a condition likely to make them not perform well.

Lack of students' involvement extends even in the governance of schools. In their studies on students' views on their participation in school governance, Mulwa et al. [13] found out that students are only involved in simpler matters like students' welfare, leaving out key issues, for instance, school management to the teachers and boards. When left out in key aspects of their school life, they may feel less important and demotivated in their academic endeavour [14].

The main aim of school discipline, according to Thungu, et al. [15], is to produce young people who will grow into responsible adults and self-disciplined individuals, who accept the consequences of their own decisions and actions. Thungu et al. [15]; Korma [16] and Addus, Chen and Khan [17] explain that discipline can be achieved in schools by involving students in decision making processes. Such involvement helps in boosting motivation to learn as suggested by Chappius [18]. To Moss [19], students' participation in matters of discipline makes them learn the importance of taking responsibility, minimizing excuses and helping one another. The net effect of this involvement is that students end up performing much better in the final examinations [20].

This study was pegged on the organizational theory postulated by Hersey and Blanchard [21]. The theory highlights an upward and downward communication trend in educational organisations. The theory's principle of communication rendered it relevant to this study. Communication here is between parents and students; teachers and students and school principals and students. It is this communication which may enable students to make informed decisions on issues that affect them, a factor that creates a conducive atmosphere for meaningful studying that improves their academic performance.

\section{Study Objectives}

This study aimed at achieving two objectives: (i) to examine whether involvement of students by parents in deciding and making choices of schools affects academic performance; and (ii) to examine whether the involvement of students by the school administration in establishing rules and disciplinary measures affects academic performance.

\section{Methodology}

Survey design was deemed appropriate for the study because it allowed the researchers to address what was happening to the students in relation to their parents and the teachers in terms of the choice of their schools and rules they adhered to in school respectively.

All the twelve public day secondary schools in Embu West Sub-County of Kenya were targeted. It was assumed that the schools under study used the same curriculum that was stipulated by the Kenya National Examinations Council, and that the Kenya Certificate of Secondary Education results together with those of other examinations done, were true reflections of a school's academic performance.

Using simple random sampling, four schools out of the 12 were selected to participate in the study. Purposive sampling was then done on the 4 schools to select students to participate. This allowed for the selection of Forms Two and Three students for inclusion in the study. The rationale was that students in these two classes had been in school long enough to express their decision making experiences. The total student population of Forms Two and Three in the Sub-County was 954. Form Four students were purposefully left out of the study because they were busy preparing for their final exam. In the same way, Form One students were judged to have insignificant experiences in schools, hence left out as well. Included in the study therefore, were Forms Three and Two students, as well as their teachers and parents. The teachers and parents to these Forms Two and Three students participated in the study as significant others in students' life in school and at home respectively.

The four sampled schools had Forms Two and Three collective student populations of $96,76,75$ and 81 respectively. This resulted in a total study population of 328 students each of whom had the same probability of being chosen for the study. A random sample of 98 students, which represents 30 percent of the total population, was drawn for the study. This percentage was found sufficient for the study's analysis according to Mugenda and Mugenda sample selection rule of thumb [22]. The parents of the 98 sampled students who were also 98 in number were included in the study. The four principals of the four sampled schools as well as Forms Two and Three teachers of the same schools were polled as well. The selected respondents were also 
individually informed that participation was voluntary, that they could skip any questions about which they felt uncomfortable answering, and that they could stop participation at any time without any reprisals. They therefore gave informed consent to their participation.

With the help of four trained research assistants, data were collected using open and closed-ended questionnaire for the students, teachers and the principals of the four schools. The questionnaires allowed the participants to freely express themselves. Parents participated through the use of focus group discussions facilitated by the four research assistants. A documentary analysis form was used to access the end of term examination results for the four schools. The four schools' end of term examination results were accessed to form the basis of measuring the dependent variable, the academic performance.

A total of 112 questionnaires were distributed. Out of these, a total of 107 questionnaires, that is, 94,10 and 3 from students, teachers and principals respectively, were accepted for analysis. This represented a response rate of 95.5 percent. The parental responses were noted down as field notes. The end-of-term examination results were noted as either good or satisfactory or poor.

The collected data were then coded and classified according to the various themes reflected in the research objectives, that is, involving students in decision making in school choices and designing rules improved their academic performance.

\section{Findings and Discussions}

In order to meet the first objective, which was to establish whether involving students in making choices of schools improved their academic performance, the students were first asked to state who had made the decision that they join their current school. It was found out that only 13\% $(n=12)$ of the respondents made the decision themselves. Another $32 \%(n=30)$ had the decision made by their parents while the other $55 \%(\mathrm{n}=52)$ had the decision jointly made by the students and their parents. This is indicated in table 1 .

Table 1. he decision maker on choice of school

\begin{tabular}{|c|c|c|c|}
\hline Category & Frequency & Percentage & Performance \\
\hline Student & 12 & 13 & Good \\
\hline Parents & 30 & 32 & Satisfactory \\
\hline $\begin{array}{c}\text { Student and } \\
\text { Parents }\end{array}$ & 52 & 55 & Good \\
\hline
\end{tabular}

The students were also asked to state whether they wished to be involved in the choice of schools. Majority of the students $93 \%(n=87)$ reported in the affirmative while $7 \%$ $(n=7)$ reported that they did not wish to be involved, thereby leaving the decision to their parents. These results are reported in table 2 .
Table 2. Students wish to be involved in decision making

\begin{tabular}{|c|c|c|}
\hline Desired to be involved & Frequency & Percentage \\
\hline Yes & 87 & 93 \\
\hline No & 7 & 7 \\
\hline
\end{tabular}

Those who preferred to be involved indicated that involvement would enable them give their views on the matter. Although a big number of the interviewed parents did not see the need of involving their children in the school choices, results indicate that involving students makes them feel motivated and mature. This makes them more responsible in their study work, leading to better performance in their end of term examinations and this is in agreement with Mulwa et al [3] and Uhumuavbi [5]. The $32 \%(n=30)$ whose decision to join their current school had been made wholly by their parents did not feel motivated, a factor that may adversely affect their academic performance. Students who made the decision themselves $(13 \%$ or $n=12)$ felt motivated and had good academic performance in their end of term examinations.

The second objective was to establish the extent to which involvement of students in establishing school rules and consequences of violating them affected academic performance. Accordingly, the 10 sampled teachers were asked whether they involved students in decisions on rule violation sanctions. Only $30 \%(\mathrm{n}=3)$ reported that they did, while the other $70 \%(n=7)$ reported that they did not. This is shown in table 3 .

Table 3. Student involvement in school rule making

\begin{tabular}{|c|c|c|c|}
\hline Involved & Frequency & Percentage & Performance \\
\hline Yes & 3 & 30 & Good \\
\hline No & 7 & 70 & Satisfactory \\
\hline
\end{tabular}

The students were asked to state to what extent they wished to be involved in decisions on appropriate sanctions for violation of school rules. About 53\% $(n=50)$ of the students reported that they wished to be "very highly" involved, 21\% $(\mathrm{n}=20)$ expressed "high" willingness and $11 \%(\mathrm{n}=10)$ expressed low willingness. Another $15 \%(\mathrm{n}=14)$ did not express the need to be involved at all. This is indicated in table 4.

Table 4. Extent of involvement in disciplining offenders

\begin{tabular}{|c|c|c|c|}
\hline Extent & Frequency & Percentage & Performance \\
\hline Very high & 50 & 53 & Good \\
\hline High & 20 & 21 & Satisfactory \\
\hline Low & 10 & 11 & Poor \\
\hline No extent & 14 & 15 & - \\
\hline
\end{tabular}

When students were asked to state to what extent they believed that their involvement in the establishment of school disciplinary measures would improve their performance, over $93 \%(n=88)$ affirmed while $7 \%(n=6)$ negated. 
The results of the study indicate that student involvement into disciplinary issues make them grow into responsible adults who accept the consequences of their own decisions and actions, an aspect that leads to improved academic performance as revealed by reviewed literature [15]. As reviewed literature confirms, students are more likely to obey their own-made rules than they are to adhere to the teachers-made rules. This makes students feel more accountable to themselves, independent in thought, and responsible in their academic work, resulting in improved performance. $[18,19]$. This is clearly indicated by correlation analysis, which showed that $90 \%(\mathrm{n}=88)$ of the involved students who recorded better mean scores than the $10 \%$ $(n=16)$ of the un-involved students.

Students' involvement in decision making and academic performance corroborates Osongo [20], who found that students learn more when they are actively involved in decision making by their parents and teachers. Having its anchorage on the organizational theory, the study advocates for a free upward and downward communication trends that are essential in an educational set up. Arising from these findings, teachers and parents should create a free atmosphere to enable students actively participate in dialogues and communicate their views about their academic work.

\section{Conclusions}

The findings of this study have important implications pertaining students' responsibility, ownership independence and maturity as well as teacher's creativity and insightfulness. The study highlights the importance of cooperation among parents, teachers and students in the students' academic performance. When parents made joint decisions with their children regarding the school in which the children will be enrolled, the children felt motivated, and mature in dealing with issues related to their academic wellbeing. And where students were involved at any one step in their educational process by teachers and parents, the students felt that they owned the decision and were ready to implement it. Ownership was realized by students' participation in decision making regarding their school choices and in formulation of school rules and disciplinary issues. This resulted in increased efforts, and as a result, good academic performance. When students were involved, they increased maturity, responsibility, independence, and rationality in their pursuit of excellence in academic performance. In cases where involvement of students lacked, there was a growing sense of demotivation and demoralization that negatively impacted on student academic performance.

\section{Recommendations}

The results of this study yielded three significant recommendations, which are tied to the study's objectives. The recommendations are:

- Good academic performance is as a result of combined effort among students, parents and teachers. The ministry of education should therefore develop a program for parents and teachers to enable them understand and appreciate the need to fully involve students in decision making on issues that concern them and their academic life, including the choice of schools.

- Rules are an integral part of a relationship whenever two or more people live and work together for a mutual purpose. In order to feel duty-bound to observe rules, students should be involved to the extent possible in formulating them. It is therefore recommended that teachers should look for ways of involving students in decision making, when school rules are formulated. In cases where some students break these rules, other students should also be involved by teachers in deciding the disciplining to be meted out to the offenders. In this way, there will be commonality and altruism as they all work together for excellence in academic performance.

- This study was delimited to the influence of students' involvement in decision making on academic performance in public day secondary schools. There is need for further studies on the influence of students' behaviour on academic performance.

\section{REFERENCES}

[1] MOEST, A policy for Education, Training and Research. Sessional paper no 1, Government Printer, Nairobi, 2005.

[2] Republic of Kenya, Task Force on the re-alignment of the education sector to the Constitution of Kenya 2010, Government Printer, Nairobi, 2013.

[3] M.D. Mulwa, K. M. Kimosop, G.M. Kavisu, Participatory Governance in Secondary schools. The Student View Point in Eastern Region of Kenya. Journal of Education and Practice. Vol. 6, No 30, 2015.

[4] H.L. Renato, W.D Norbert., P.M. Rafael, Y.A Cibele, Academic Performance. Students' background and Affirmative Action at a Brazilian University. Higher Education Management and Policy, Vol. 19, No 3, 2007

[5] P.O. Uhumuavbi, J.A. Mamudu, Relative effects of programmed instructions and demonstration methods in students' academic performance in science, College Student Journal, Vol. 18, 7-10, 2007.

[6] J.K. Kiumi, J. Bosire, A.K. Sang, The study relationship between principals' management approaches and students' in public secondary schools in Nyandarua and Laikipia districts, Kenya. Global journal of Educational Research, Nairobi, 2009. 
[7] The Kenya National Examination Council, The 2009-2013KCSEExamination Reports. Nairobi: KNEC.

[8] United Nations, Convention on the Right of the Child, Geneva. 1996-2002.

[9] J.W. Korma, An investigation on factors contributing to students' strikes in public schools. Unpublished research project on Education. University of Nairobi, 2007.

[10] D.M. Mbiti, Foundations of school administration. Oxford University Press, 2009.

[11] O. Abagi, Public and private investment in primary education in Kenya: An agenda for action, Nairobi, The legal press Kenya, Ltd, Nairobi, 1997.

[12] B.T. Jeruto, C. J. Kiprop, Extent of Student participation in decision making in secondary schools in Kenya. International Journal of Humanities and Social Sciences. Vol 1 No.21, 2011.

[13] MOEST, Report of the Task Force on Students Discipline and Unrest in Secondary schools, Government Printer, Nairobi, 1999.

[14] J. Thungu, K. Wandera, L. Gachie, G. Alumande, Mastering PTE Education, Oxford University Press, Nairobi, 2008.

[15] A.A. Addus, D. Chen, S. Khan, Academic Performance and
Advisement of University Students. A case Study. College student journal of Project Innovation, 228-238, 2008.

[16] J. Chappuis, Helping students understand assessment. Educational Leadership, vol 63, no 3, pp39-43, 2005.

[17] L. Moss, The Importance of Goal Setting for Students, Online available from http; ww.ehow.com/facts.

[18] G.E. Eshiwani, Education in Kenya since independence, East African Educational Publishers, Nairobi, 1993

[19] P Eggen, D Kauchak, Educational Psychology: Windows on classrooms, 9th edn, Pearson, New Jersey, 2013.

[20] J. Kauffman, Secondary school strikes, the art of blaming the victims. Discussion paper No 243. University of Nairobi, 2007

[21] J.A. Okumbe, Education Management Theory and Practice, University of Nairobi Press, Nairobi, 1998.

[22] O. Mugenda, A. Mugenda, Research methods. Africa Centre for Technology Studies, Nairobi, 2003.

[23] A. Woolfolk, Educational Psychology, 12th edn, Pearson, New Jersey, 2013.

[24] J.K. Osongo, Christian Religious education in Secondary Schools, Catholic University of Eastern Africa, Nairobi, 2010. 